\title{
The amphibians of Ranomafana rain forest, Madagascar - preliminary community analysis and conservation considerations
}

\author{
Franco Andreone
}

Surveys of the amphibians (Order: Anura) of Ranomafana National Park, a midaltitude rain forest in central-eastern Madagascar, and nearby areas of disturbed habitats were carried out in two seasons (December 1991 and August 1992). A total of 40 frog species was recorded. In undisturbed areas many strictly terrestrial species were present, most of them belonging to the endemic family Mantellidae. These species showed changes in abundance between August and December, probably due to temperature variation. In contrast, most of the species found in altered habitats were arboreal or semiarboreal. These are 'ecologically opportunistic' species, not so sensitive to habitat variations and able to reproduce whenever conditions are favourable. These species were equally abundant in December and August and they appear to be able to live in a more varied habitat patchwork. To preserve the diversity and abundance of amphibians, nature reserves should retain a central core of primary forest to ensure the survival of the more specialized species, surrounded by a buffer zone of degraded vegetation to sustain the presence of more adaptable frog species.

\section{Introduction}

Rain forests are among the most interesting natural habitats in Madagascar. Once distributed almost continuously along the eastern coast, they are now highly fragmented (Green and Sussman, 1990). Only about 6 per cent of the remaining forests are protected and it is a commonly held opinion that in about 10 years 99 per cent of them will have disappeared (Raxworthy, 1988). The negative effects of such habitat fragmentation on reptiles were discussed by Raxworthy (1988), but detailed studies of the ecology and distribution of amphibians have not been carried out. These vertebrates show a high degree of adaptive radiation, with more than 150 species (all in five families in the order Anura) currently known in Madagascar (Glaw and Vences, 1992). The mantellids are endemic to Madagascar: sometimes considered a subfamily of ranids (Blommers-Schlösser, 1979, 1993; BlommersSchlösser and Blommers, 1984) they have mor- phological characters intermediate between ranids and rhacophorids. Furthermore, they are characterized by several features related to mating and reproduction. For example, they lack nuptial pads but have femoral glands, although in many Mantella and Mantidactylus spp. the latter may not be clearly visible (Glaw and Vences, 1992). They include species that are strictly terrestrial (e.g., Mantidactylus opiparis), aquatic (e.g., M. lugubris) and arboreal (e.g., M. aglavei or the species of $M$. pulcher group, which live in leaf axils). One endemic genus, Mantella, shows convergent features with the neotropical dendrobatids, having sharply contrasting aposematic coloration associated with toxic skin (Andreone, 1992). Rachophorids are represented by tree-frogs of the endemic genus Boophis and by the monospecific terrestrial genus Aglyptodactylus. Malagasy rhacophorids differ from their Asiatic and African relatives in laying their eggs in water and not being foam-nestbuilders. Ranids include the adaptable and 


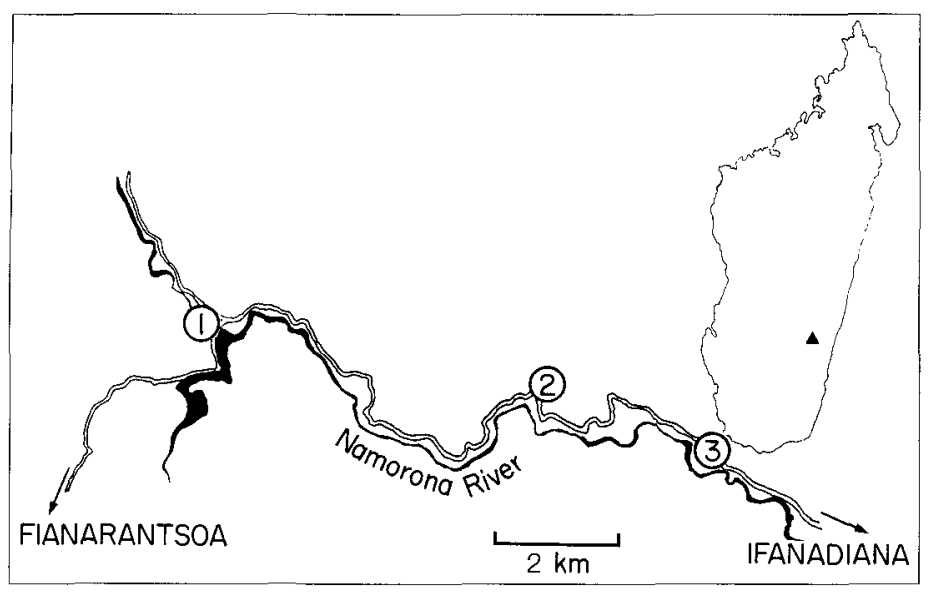

Figure 1. The surveyed area, with the villages of Vohiparara (1) Ambatolahy (2), Ranomafana (3) and the Namorona River (in black). The map of Madagascar shows the location of the Ranomafana National Park. Based on 'Alakamisy Ambohimaha' and 'Ifanadiana' geographical maps (IGN, 1973a,b). widely distributed Ptychadena mascareniensis, which also occurs in continental Africa and the Mascarene Islands, and Limnonectes tigerinus (introduced) and Tomopterna labrosa in the western and southern regions of the country. Microhylids are represented by 10 genera (Glaw and Vences, 1992), some of which are terrestrial (for example, Dyscophus, Scaphiophryne, Plethodontohyla) and some arboreal (for example, Platypelis and Anodonthyla). The Malagasy hyperoliids are represented by the endemic genus Heterixalus, which is strictly arboreal.

Because amphibians are said to be declining all around the world and are particularly sensitive to habitat alteration (Blaustein and Wake, 1990) a programme must be planned to understand their biology and distribution, paying particular attention to high biodiversity areas such as Madagascar.

Surveys of amphibians have been carried out in some rain forests in Madagascar (Andreone, 1991, 1993a); at some of the sites research has been done on the natural history of some species (for example, Mantella spp. and Boophis spp., Andreone 1992, 1993b) and on the relationship between acoustic emissions and habitat frequented (Andreone and Piazza, 1992).

This paper presents the results of research carried out in Ranomafana (a rain forest of the central-eastern region), providing preliminary data on the abundance and species richness of anurans in relation to habitat alteration.

\section{Materials and methods}

\section{Study site}

The Ranomafana National Park was gazetted mainly to protect the rare golden bamboo lemur Hapalemur aureus (Meier et al., 1987; Nicoll and Langrand, 1989) (Figure 1). It is situated at $800-1200 \mathrm{~m}$ a.s.l. and the temperature ranges from 3 to $35.1^{\circ} \mathrm{C}$, with the hottest period being December-January. While there is no dry season, the rainfall is not distributed evenly: rain falls on about 200 days a year, with the maximum being in January and the minimum in October (Razafimamonjy, 1988).

\section{Survey methods}

In December 1991 and August 1992, amphibians were surveyed by means of diurnal and nocturnal searches, the latter using torchlight. The techniques employed consisted mainly of localizing individuals after hearing their calls and examining refuges, for example decaying trees, leaf axils, fallen leaves, tree holes. Field work occupied about 50 hours each month, the time being divided approximately equally between day and by night. Every individual was recorded by species, date, locality and habitat. A small number of voucher specimens were caught and photographed; these are now held in the herpetological collection of the Museo regionale de Scienze naturali, Turin. Species identification was based on the keys 
and photographs provided by BlommersSchlösser and Blanc (1991) and Glaw and Vences (1992). To support identification, advertisement calls were recorded, analysed (Andreone, 1992; Andreone and Piazza, 1992) and successively compared to sonagrams and oscillograms provided by Blommers-Schlösser and Blanc (1991) and Glaw and Vences (1992).

\section{Habitat and species categorization}

The habitats in the study fell into two broad categories: (i) undisturbed (or relatively undisturbed forest) and (ii) disturbed habitats. The first category included both primary and mature secondary rain forests, which are well represented within the national park boundaries, along the Namorona River and near Vohiparara village. Disturbed habitats included young secondary forest, scrub along roadsides, banana plantations, forest vegetation on river banks, and other areas altered by humans.

The anurans of Ranomafana may show a clear habitat preference (occurring exclusively in unaltered or disturbed habitats), or may be found mainly in one of these broad habitat categories. The species found exclusively or mainly in unaltered habitats were classified as 'primary-forest-orientated', while those found exclusively, or mainly, in degraded habitats were classified as 'disturbed-forest-orientated'. Frogs were also classified according to habitat preference/vertical distribution. As far as habitat preferences were concerned, the following categories were recognized (see Table 1): (a) terrestrial species, which usually do not climb, or which may burrow underground; (b) aquatic species, living beside and within forest streams or in still water; (c) low-arboreal species, which climb the forest vegetation to a height of 1-2 $\mathrm{m}$; (d) high-arboreal species, which usually live on trees higher than 1-2 m. A wider distinction is possible between 'nonarboreal' (categories a and b) and 'arboreal' (c and d) species.

Abundance indices (AI) (referring to the survey in the entire area) were assigned to each species in each habitat according to Crump (1971) and Toft and Duellman (1979),
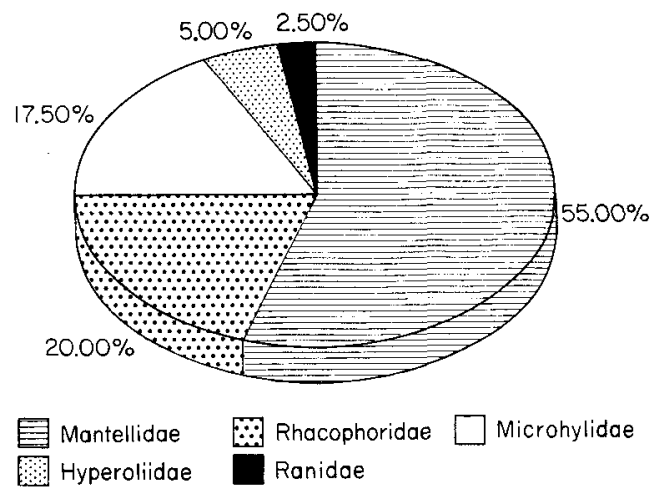

Figure 2. A pie-chart showing the proportions of the Anuran families found at Ranomafana National Park.

with some modifications as follows: $0=$ apparently absent (none observed); 1 = not commonly seen $(<5) ; 2=$ moderately common (5-10); $3=$ common (10-20); and $4=$ abundant ( $>20$ observations). The average abundance index (AAI) was obtained by dividing the sum of the abundance indices for all the species in a given habitat or period by the relative total number of species (Crump, 1971).

\section{Results}

\section{Faunal composition}

A total of 40 species was recorded (Table 1 ), probably representing only a part of the total Ranomafana amphibian fauna. Of these 22 were mantellids, one was a non-endemic ranid, eight were rhacophorids, seven were microhylids and two were hyperoliids (Figure 2).

\section{Spatial and seasonal distribution}

Of the total number of species, 27.5 per cent were found exclusively in unaltered forest (45.5 per cent of them represented by Mantidactylus spp. and 54.5 per cent by microhylids), 22.5 per cent were found only in disturbed environments, while the remaining 50.0 per cent showed no evident preferences (Figure 3). Community composition varied 
Table 1. Amphibians found in Ranomafana National Park, central-eastern Madagascar

\begin{tabular}{|c|c|c|c|c|c|}
\hline \multirow[b]{2}{*}{ Family and species } & \multirow[b]{2}{*}{ Habitat } & \multicolumn{2}{|c|}{ Vertical distribution } & \multicolumn{2}{|c|}{ Seasonal abundance } \\
\hline & & Day & Night & December & August \\
\hline \multicolumn{6}{|l|}{ Ranidae } \\
\hline 1. Ptychadena mascareniensis & $\mathrm{D}$ & WG & WG & 4 & 3 \\
\hline \multicolumn{6}{|l|}{ Mantellidae } \\
\hline 2. Mantella madagascariensis & PD & G & G & 2 & 0 \\
\hline 3. Mantidactylus aglavei & PD & $\mathrm{H}$ & $\mathrm{H}$ & 2 & 0 \\
\hline 4. Mantidactylus asper & $\mathrm{D}$ & GL & GL & 2 & 0 \\
\hline 5. Mantidactylus betsileanus & $\mathrm{DP}$ & G & G & 4 & 4 \\
\hline 6. Mantidactylus biporus & $\mathrm{PD}$ & GW & GW & 2 & 0 \\
\hline 7. Mantidactylus blommersae & $\mathrm{P}$ & G & GL & 2 & 1 \\
\hline 8. Mantidactylus cornutus & $\mathrm{P}$ & $\mathrm{L}$ & $\mathrm{L}$ & 2 & 2 \\
\hline 9. Mantidactylus curtus & PD & GW & GW & 2 & 0 \\
\hline 10. Mantidactylus depressiceps & $\mathrm{D}$ & $\mathrm{L}$ & $\mathrm{LH}$ & 0 & 3 \\
\hline 11. Mantidactylus femoralis & $\mathrm{DP}$ & G & GL & 2 & 2 \\
\hline 12. Mantidactylus grandidieri & PD & W & $\mathrm{W}$ & 3 & 3 \\
\hline 13. Mantidactylus grandisonae & $\mathrm{D}$ & GL & GL & 3 & 0 \\
\hline 14. Mantidactylus guttulatus & PD & $W$ & W & 1 & 1 \\
\hline 15. Mantidactylus liber & $\mathrm{PD}$ & $\mathrm{LH}$ & LH & 3 & 3 \\
\hline 16. Mantidactylus lugubris & $\mathrm{PD}$ & W & WL & 3 & 3 \\
\hline 17. Mantidactylus luteus & $\mathrm{P}$ & GL & $\mathrm{LH}$ & 3 & 2 \\
\hline 18. Mantidactylus majori & $\mathrm{P}$ & W & WL & 3 & 3 \\
\hline 19. Mantidactylus mocquardi & PD & WG & WL & 2 & 2 \\
\hline 20. Mantidactylus plicifer & PD & G & $\mathrm{L}$ & 3 & 2 \\
\hline 21 Mantidactylus opiparis & $\mathrm{P}$ & G & $\mathrm{G}$ & 3 & 2 \\
\hline 22. Mantidactylus pulcher & PD & $\mathrm{LH}$ & LH & 3 & 1 \\
\hline 23. Mantidactylus cf. wittei & $\mathrm{D}$ & G & GL & 2 & 1 \\
\hline \multicolumn{6}{|l|}{ Rhacophoridae } \\
\hline 24. Aglyptodactylus madagascariensis & $\mathrm{PD}$ & G & G & 4 & 0 \\
\hline 25. Boophis albipunctatus & DP & $\mathrm{H}$ & $\mathrm{H}$ & 1 & 1 \\
\hline 26. Boophis erythrodactylus & $\mathrm{D}$ & LH & $\mathrm{HL}$ & 0 & 3 \\
\hline 27. Boophis luteus & $\mathrm{DP}$ & $\mathrm{H}$ & $\mathrm{H}$ & 3 & 2 \\
\hline 28. Boophis madagascariensis & $\mathrm{DP}$ & $\mathrm{LH}$ & $\mathrm{LH}$ & 3 & 4 \\
\hline 29. Boophis cf. miniatus & $\mathrm{D}$ & $\mathrm{LH}$ & $\mathrm{HL}$ & 1 & 3 \\
\hline 30. Boophis cf. reticulatus & $\mathrm{PD}$ & $\mathrm{LH}$ & HL & 2 & 4 \\
\hline 31. Boophis sp. & $\mathrm{DP}$ & $\mathrm{H}$ & $\mathrm{H}$ & 2 & 1 \\
\hline \multicolumn{6}{|l|}{ Microhylidae } \\
\hline 32. Anodonthyla boulengeri & $\mathrm{P}$ & LH & $\mathrm{H}$ & 2 & 2 \\
\hline 33. Plethodontohyla inguinalis & $\mathrm{P}$ & G & G & 1 & 0 \\
\hline 34. Plethodontohyla notosticta & $\mathrm{P}$ & $\mathrm{G}$ & G & 2 & 0 \\
\hline 35. Platypelis grandis & PD & $\mathrm{LH}$ & $\mathrm{HL}$ & 2 & 0 \\
\hline 36. Platypelis cf. pollicaris & $\mathrm{P}$ & $\mathrm{HL}$ & $\mathrm{HL}$ & 3 & 3 \\
\hline 37. Platypelis tuberifera & $P$ & $\mathrm{LH}$ & $\mathrm{LH}$ & 2 & 1 \\
\hline 38. Scaphiophryne marmorata & $P$ & $\mathrm{G}$ & $\mathrm{G}$ & 2 & 0 \\
\hline \multicolumn{6}{|l|}{ Hyperoliidae } \\
\hline 39. Heterixalus alboguttatus & $\mathrm{D}$ & $\mathrm{LH}$ & $\mathrm{LH}$ & 0 & 3 \\
\hline 40. Heterixalus betsileo & $\mathrm{D}$ & $\mathrm{LH}$ & $\mathrm{LH}$ & 4 & 0 \\
\hline
\end{tabular}

Species with 'cf' are of uncertain determination or taxonomic status; Boophis sp. refers to an undescribed species of the Boophis luteus group (sensu Glaw and Vences, 1992). P, primary forest/unaltered habitat; D, disturbed/altered habitat. $G$, ground, forest litter; $W$, water; $L_{t}$ low vegetation; $H$, high vegetation and forest canopy. When two letters are paired the first indicates the habitat or level where the species has been more frequently found. 0 , apparently absent (none observed); 1 , not commonly seen ( $<5$ observed); 2 , moderately common (5-10); 3, common (10-20); 4 , abundant ( $>20$ observations). 


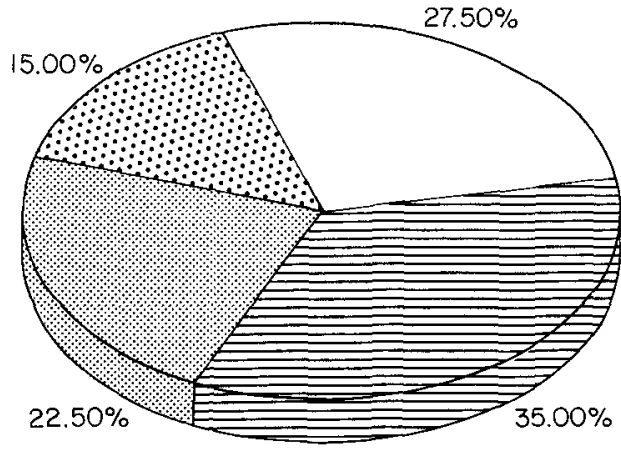

Habitats

$\begin{array}{ll}\square \text { unaltered } & \text { disturbed } \\ \text { 国 unaltered/disturbed } & \because \text { disturbed/unaltered }\end{array}$

Figure 3. A pie-chart showing the habitat preference of the amphibians found in four types of habitats: unaltered, species exclusively found in unaltered forest; unaltered-disturbed, species found more abundantly in undisturbed environments (but also, although in lower abundance, in altered habitats); disturbed, species found exclusively in altered habitats; disturbed-unaltered, species found more abundantly in disturbed environments (but also, although in lower abundance, in unaltered habitats).

between the two months studied: 37 species (92.5 per cent of the total) were found in December and 28 (70.0 per cent) in August; 12 species (30.0 per cent) were found only in December, three species ( 7.5 per cent) only in August and 25 (62.5 per cent) in both months. The faunal composition and abundance indices in December and August were significantly different (Wilcoxon test, $P=0.031$ ). Of the species found in degraded habitats 60.0 per cent were active in both months, and their AIs did not differ significantly between the two months (Wilcoxon test, $P=0.937$ ). Some of these species (for example, Ptychadena mascareniensis, Mantidactylus betsileanus and Boophis luteus called both in August and in December and probably were opportunistic breeders, laying eggs throughout the year. The 'primary-forest-orientated' species showed a significant AI difference (Wilcoxon test, $P=$ 0.002 ) and appeared to breed only in the warmest months.

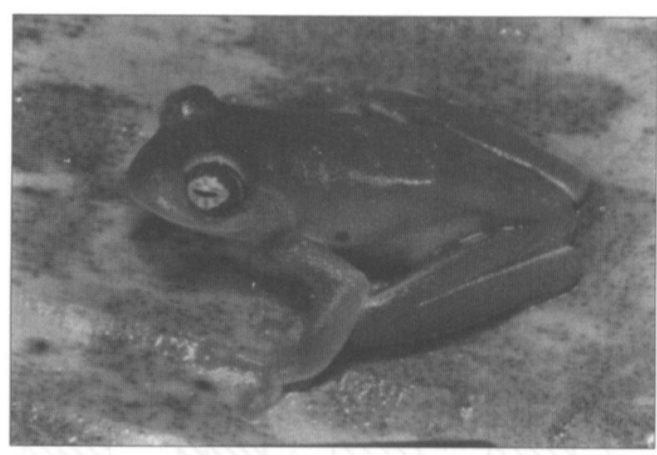

Boophis luteus, an arboreal species found abundantly in open areas in the forest or in disturbed habitats (F. Andreone).

The AAI is significantly higher in December (2.28) than in August (1.60) if calculated using all the species (Mann-Whitney test, $U=2.502$, $P=0.014)$, but similar (2.43 and 2.21) if calculated using only the species found in that period (AI $>1 ; n=37$ and $n=28 ; U=470, P=$ 0.504 ). Thus, the species that are present in both periods do not seem to change significantly in abundance. The AAI of the 'disturbed-forest-orientated' species $(n=15)$ does not differ in the considered periods (in December $=2.067$; in August $=2.000 ; U=110$, $P=0.916$ ), but differs in the 'primary-forestorientated' species $(n=25)$ (in December $=2.40$; in August $=1.36 ; U=165, P=0.003$ ). The more adaptable species, therefore, maintain similar abundances in both the considered periods, whereas those more strictly confined to unaltered habitats are more sensitive and show seasonality.

One aspect of microhabitat partitioning, namely arboreality/terrestriality, coincided with the basic dichotomy of diel activity period between night and day. None of the exclusively arboreal species, including all the Boophis species ( 38.9 per cent of the total), is diurnal. Finer distinctions can be made among the arboreal species, because different frog species utilize different habitats (for example, canopy, Pandanus palms, trunks, leaf axils). Some arboreal microhylids (for example, Platypelis, Anodonthyla) live in bamboo internodes, holes in tree trunks and in leaf axils. 


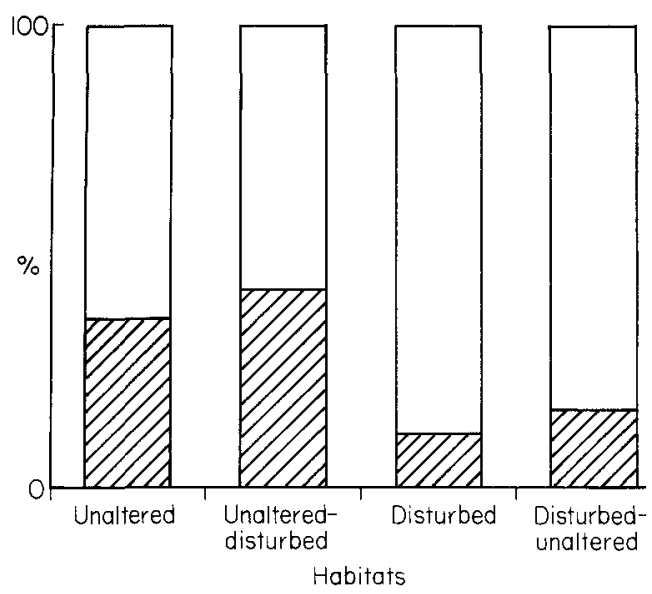

Figure 4. Histograms of the arboreal (and semiarboreal) (unshaded) and terrestrial (and/or aquatic) species (shaded) (expressed as percentages) in four types of habitats: unaltered, species exclusively found in unaltered forest; unaltereddisturbed, species found more abundantly in undisturbed environments (but also, although in lower abundance, in altered habitats); disturbed, species found exclusively in altered habitats; disturbed-unaltered, species found more abundantly in disturbed environments (but also, although in lower abundance, in unaltered habitats).

Twelve species are terrestrial or aquatic (for example, Mantidactylus majori), 58.3 per cent of which are mantellids. Ten species were semiarboreal, all belonging to the genus Mantidactylus (e.g. M. cornutus). During the day these species are terrestrial (or partly aquatic), while at night they climb into the lower layers of the forest vegetation, often to make their breeding calls. Different species may use different microhabitats (or parts of the forest) as sites of activity or as refuges and little is known about activity in the upper storey of the forests. Most arboreal and semiarboreal species (all the rhacophorids except Aglyptodactylus, many microhylids and Mantidactylus) move from their diurnal retreats to nocturnal breeding sites, usually temporary or permanent ponds. Only 11.1 per cent of the species found in disturbed habitats and 16.7 per cent of those classified as 'disturbed-forest-orientated' were terrestrial or aquatic, while of the species found exclusively or mainly in undisturbed habitats, 36.4 and

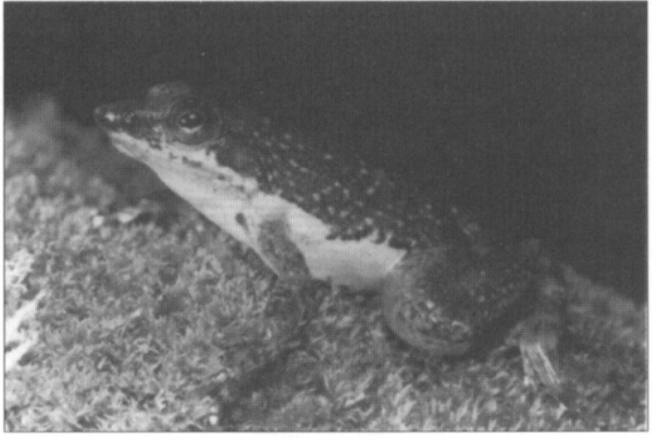

Mantidactylus majori is a stream frog, found mainly in unaltered areas (F. Andreone).

42.9 per cent, respectively, were terrestrial or aquatic (Figure 4).

\section{Discussion}

The 40 species of anurans observed in Ranomafana show high diversity in habitat preference and in annual and diel cycles of activity, stressing the high conservation value of this protected rain forest. Most of the frogs found in altered habitats were arboreal Boophis spp. while other species (e.g., Heterixalus alboguttatus, Mantidactylus cf. wittei and M. asper) were also found beside asphalted roads or in plantations. They do not seem to depend upon the microclimatic conditions of the forest floor: most probably the natural habitat of these species was the overstorey canopy of the open areas inside primary forest, as hypothesized by Raxworthy (1988) for chameleons. Many of these species are opportunistic breeders, breeding whenever habitat conditions are favourable for the development of tadpoles.

Although, as pointed out by Nicoll and Langrand (1989) there is not a real dry season at Ranomafana, some species (particularly those that are primary-forest orientated) require the higher temperature and rainfall of the warmest months to be active and breed. When the temperature is low some species become inactive. It is probable that the high number of frog species in this area is also due to a narrow niche segregation, not only in daily activity, but also throughout the seasons. 


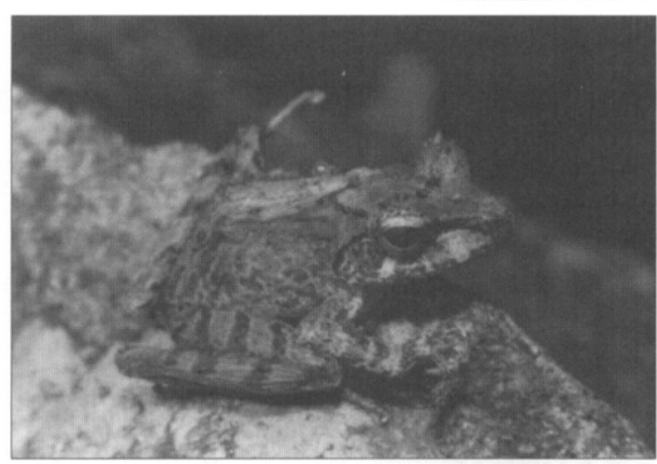

Mantidactylus cornutus is a semiarboreal species found either in primary rain forest (along streams) or in man-altered areas (F. Andreone).

A considerable number of the 'primary-forestorientated' species are terrestrial $(10$ species out of 25) and were found in only one of the months under study. Most probably these are 'K-orientated species', which rely on the stability of the environment. In fact, many of the terrestrial species strictly confined to the leaf litter (for example, Mantidactylus opiparis and Plethodontohyla inguinalis) seem to be generally less tolerant of habitat alteration and are more specialized in their habitat requirements.

Most of the species recorded in degraded habitats did not differ in seasonal activity, being similarly abundant in both the analysed periods. It is argued that, being opportunistic species, they are less subject to climate variations and are active throughout the year. Another group of species (which includes Mantella madagascariensis, Mantidactylus lugubris and Aglyptodactylus madagascariensis) occurred originally in unaltered or primary rain forest, but may now be found in some degraded parcels as well as along rivers. It is possible that in these habitats, although altered, ecological conditions (like temperature and humidity) are relatively stable.

Thus, it may be hypothesized that the rapid exploitation of the Malagasy rain forests will cause general declines in many terrestrial species closely linked to unaltered habitats and leaf litter. The observation that arboreal or semiarboreal species and those living in swamps and streams still survive (and sometimes are also abundant) in disturbed environments supports the idea that they may adapt to altered environments. The main problem facing tropical rain-forest management and protection is fragmentation and isolation. Raxworthy (1988) suggested an island archipelago' approach (Harris, 1984), with the creation of vegetation corridors between reserves. But this, in reality, would be difficult to implement. It might be easier to maintain an outer buffer zone of degraded vegetation around the primary rain forest to support high species diversity. In the core of the reserve highly specialized frog species may survive, whereas in the more extended degraded belt arboreal species may be found. Careful analysis of the ecological relationships between amphibian species and their habitats, together with the level of endemism and community richness, should be taken into account when selecting areas to be strictly protected. A study programme on the distribution of Malagasy frogs and the community composition of other rain forests (and also of several interesting deciduous forests of western Madagascar) is therefore needed to establish conservation priorities.

\section{Acknowledgments}

This work has been carried out in collaboration with the Botanic and Zoological Park of Tsimbazaza (Project for the Study and Conservation of Madagascan Amphibians - Tetik'asa ho Fianarana sy Fikajiana ny Sahona Malagasy). E. 'Rajeri' Rajeriariason and J.-E. 'Fidi' Rafidison provided their experience to locate the sites in the field. $R$. Blommers-Schlösser, F. Glaw and M. Vences were of help in species identification.

\section{References}

Andreone, F. 1991. Conservation aspects of the herpetofauna of Malagasy rain forests. Società Zoologica 'La Torbiera' - Scientific Reports, 1, 1-45.

Andreone, F. 1992. Syntopy of Mantella cowani Boulenger and Mantella madagascariensis Grandidier in central-eastern Madagascar, with notes on the coloration in the genus Mantella (Anura: Mantellidae). Boll. Mus. reg. Sci. nat. Torino, 10 (2), 421-450.

Andreone, F. 1993a. Kommentierte Liste von Amphibienfunden auf Madagaskar. Salamandra, $29(3 / 4), 200-211$.

Andreone, F. 1993b. Two new treefrogs of the genus 
Boophis (Anura: Rhacophoridae) from central-eastern Madagascar. Boll. Mus. reg. Sci. nat. Torino (in press).

Andreone, F. and Piazza, R. 1992. Aspetti bioacustici [ed ecologici) in alcune specie di Anfibi delle foreste pluviali malgasce. 54th UZI Congress (Perugia, Italy). Riassunti, 53-54.

Blaustein, A.R. and Wake, D.B. 1990. Declining amphibian populations: a global phenomenon? Trends in Ecology and Evolution, 5 (7), 203-204.

Blommers-Schlösser, R.M.A. 1979. Biosystematics of the Malagasy frogs. I. Mantellinae (Ranidae). Beaufortia, 352 (29), 1-75.

Blommers-Schlösser, R.M.A. 1993. Systematic relationships of the Mantellinae Laurent 1946 (Anura Ranoidea). Ethology, Ecology and Evolution, 5, 199-218.

Blommers-Schlösser, R.M.A. and Blanc, Ch.P. 1991. Amphibiens (première partie). Faune de Madagascar, 75 (1).

Blommers-Schlösser, R.M.A. and Blommers, L.H.M. 1984. The amphibians. In Key Environments: Madagascar (ed. A. Jolly), pp. 89-104. Pergamon, Oxford

Crump, M.L. 1971. Quantitative analysis of the ecological distribution of a tropical herpetofauna. Occas. Pap. Mus. Nat. Hist. Univ. Kansas, 3, 1-61.

Glaw, F. and Vences, M. 1992. A Fieldguide to the Amphibians and Reptiles of Madagascar. Vences and Glaw Verlag, Köln.

Green, G.M. and Sussman, R.W. 1990. Deforestation history of the eastern rain forest of Madagascar from satellite images. Science, 248, 212-215.

Harris, L.D. 1984. The Fragmented Forest: Island Biogeography Theory and the Preservation of Biotic
Diversity. The University of Chicago Press, Chicago and London.

IGN (Institute Geographique National). 1973a. Feuille 0 - 53 Nord, 'Alakamisy Ambohimaha'. Carte de Madagascar au 1/50.000. Paris (Centre à Madagascar).

IGN (Institute Geographique National). 1973b. Feuille - 53 Nord, 'Ifanadiana'. Carte de Madagascar au 1/50.000. Paris (Centre à Madagascar).

Meier, B., Albignac, R., Peyriéras, A., Rumpler, Y. and Wright, P. 1987. A new species of Hapalemur (Primates) from south east Madagascar. Folia primatol. 48, 211-215.

Nicoll, M.E. and Langrand, O. 1989. Madagascar: Revue de la Conservation et des Aires Protégées. WWF, Gland.

Raxworthy, C.J. 1988. Reptiles, rainforest and conservation in Madagascar. Biol. Cons. 43, 181-211.

Razafimamonjy, D. 1988. Etude d'un écosystème forestier de Ranomafana. In L'equlibre des écosystèmes forestiers á Madagascar. Actes d'un séminaire international (eds L. Rakotovao, V. Barre and J. Sayer), pp. 315-319. IUCN, Gland and Cambridge.1988.

Toft, C.A. and Duellman W.E. 1979. Anurans of the lower Rio Llullapichis, Amazonian Perù: a preliminary analysis of community structure. Herpetologica, 35, 71-77.

Franco Andreone, Museo regionale di Scienze naturali, Division of Zoology, via G. Giolitti 36, 10123 Turin, Italy and Parc Botanique et Zoologique de Tsimbazaza, BP 4096, Antananarivo 101, Madagascar. 